\title{
New Perspectives in Applying the Regression- Discontinuity Design for Program Evaluation: A Simulation Analysis
}

Sally A. Lesik

Central Connecticut State University, lesiks@ccsu.edu

Follow this and additional works at: http://digitalcommons.wayne.edu/jmasm

Part of the Applied Statistics Commons, Social and Behavioral Sciences Commons, and the Statistical Theory Commons

\section{Recommended Citation}

Lesik, Sally A. (2011) "New Perspectives in Applying the Regression-Discontinuity Design for Program Evaluation: A Simulation Analysis," Journal of Modern Applied Statistical Methods: Vol. 10 : Iss. 1 , Article 18.

DOI: $10.22237 /$ jmasm/1304223420

Available at: http://digitalcommons.wayne.edu/jmasm/vol10/iss1/18

This Regular Article is brought to you for free and open access by the Open Access Journals at DigitalCommons@WayneState. It has been accepted for inclusion in Journal of Modern Applied Statistical Methods by an authorized editor of DigitalCommons@WayneState. 


\title{
New Perspectives in Applying the Regression-Discontinuity Design for Program Evaluation: A Simulation Analysis
}

\author{
Sally A. Lesik \\ Central Connecticut State University, \\ New Britain, CT, USA
}

Evaluating educational programs is a core component of assessment. One challenge occurs because participants often enter into programs with diverse skills and backgrounds. The regression-discontinuity design has been used to evaluate programs amongst a diverse group, but noncompliance is a limitation. A simulation analysis illustrates the impact of noncompliance.

Key words: Education, program evaluation, Monte Carlo simulation, regression-discontinuity design, ordinary least squares regression, noncompliance.

\begin{abstract}
Introduction
Evaluating the effectiveness of educational programs can pose a challenge for researchers. One reason is because it is very difficult to isolate a program effect versus the effect attributed to differences between students who participate in such programs. Most evaluative studies compare different and diverse groups of students with respect to how well they perform by relying on observational versus experimental data. In order to estimate an actual program effect versus estimating differences between program participants, many studies have incorporated the regression-discontinuity design (Thistlethwaite \& Campbell, 1960). The regression-discontinuity design allows for making causal inferences about program effects as the design has properties similar to a random experiment (Leake \& Lesik, 2007; Lesik, 2006; Luyten, 2006; Moss \& Yeaton, 2006).
\end{abstract}

The regression-discontinuity design has become a popular statistical tool for program evaluation because when a prescribed pretreatment assignment measure is available, the regression-discontinuity design can emulate a

Sally A. Lesik is an Associate Professor in the Department of Mathematical Sciences. Her research interests are in applied statistical inference for educational research.

Email her at: lesiks@ccsu.edu. random experiment (Pettersson-Lidbom, 2003). Because the design resembles a random experiment, it can be used to estimate a program effect versus simply describing differences between different groups of individuals (Lesik, 2007).

Although the regression-discontinuity can be used to evaluate educational programs, the design has some major limitations that can make it difficult to apply in practice. One limitation of the design is that it assumes that the functional form of the model is specified correctly (Schumacker \& Mount, 2007). Given the correct model specification, the regressiondiscontinuity design can provide an unbiased estimate of the program effect (Shadish, Cook \& Campbell, 2002). However, if the functional form of the model is not known - and therefore not specified correctly - then any inferences made using a regression-discontinuity analysis may be biased and unreliable (Schumacker \& Mount, 2007; Shadish, et al., 2002).

Another limitation is that the regressiondiscontinuity design requires approximately three times as many participants to achieve adequate power compared to a true random experiment (Cappelleri, Darlington \& Trochim, 1994). Thus, a large sample is needed in order to have sufficient power to detect an effect if such an effect were to exist (Cappelleri, et al., 1994; Shadish, et al., 2002). Considering these two limitations together, it can be challenging for researchers in less-than-perfect situations to use 
the regression-discontinuity design. However, one of the more serious limitations of the regression-discontinuity design is the issue of noncompliance. Noncompliance occurs if some of the participants do not adhere to their treatment assignment based on the score they received on the pre-treatment assignment measure.

The purpose of this study is to provide a simulation analysis using the regressiondiscontinuity design to address the issue of noncompliance within the framework of ordinary least squares regression. Using Monte Carlo techniques to simulate a regression-discontinuity analysis with different sample and effect sizes along with various degrees of noncompliance, this paper illustrates how noncompliance can bias the estimate of the treatment effect. A set of guidelines is developed that researchers can use to determine if the degree of noncompliance is severely biasing the estimate of the treatment parameter.

Theoretical Background

Many researchers have used the regression-discontinuity design to evaluate the effectiveness of educational programs (Jacob \& Lefgren, 2002; Leake \& Lesik, 2007; Lesik, 2006; Moss \& Yeaton, 2006; Ross \& Lacey, 1983). One of the core requirements for using the regression-discontinuity design is that a pretreatment assignment measure with a defined cutoff score is used as the sole mechanism for assigning participants to either the treatment group or the control group. When given such a pre-treatment assignment measure, those individuals who score just below and just above a defined cutoff score will be similar to what a true random assignment would generate (Shadish, et al., 2002; Thistlethwaite \& Campbell, 1960; Trochim, 1984; vanDerKlaauw, 2002).

If such an assignment measure is used, then an unbiased estimate of the program effect can be found by interpreting the estimated parameter $\left(\hat{\beta}_{1}\right)$ at the cutoff score that is associated with the dichotomous treatment variable (TREATMENT) in a baseline regression-discontinuity equation (Lesik, 2008; Shadish, et al., 2002). A baseline regression- discontinuity equation requires that the assignment variable (ASSIGNMENT) and treatment indicator variable (TREATMENT) be included in a regression model as is illustrated in equation (1).

$$
Y=\beta_{0}+\beta_{1} \text { TREATMENT }+\beta_{2} \text { ASSIGNMENT }+\varepsilon
$$

Although the baseline regressiondiscontinuity design involves a very simple model (there are only two predictor variables represented in the model), there are some major limitations of the regression-discontinuity design. One such limitation is that the design requires the correct model specification between the assignment and outcome measure (Shadish, et al., 2002). Another limitation is that a larger sample size is needed for the regressiondiscontinuity design as compared to a true random experiment (Cappelleri, et al., 1994). Furthermore, it is expected that participants will adhere to their assignment, and not enter the treatment group if they were assigned to the control group or vice-versa.

The regression-discontinuity design requires that the regression model under consideration has the correct functional form with respect to the relationship between the assignment variable and the outcome measure of interest. For example, if the relationship between the assignment and outcome variables is linear, then the baseline regression-discontinuity model as given in equation (1) would suffice because this equation describes a linear relationship. However, if there is a non-linear relationship between the assignment and outcome variables, then using equation (1) would generate a biased estimate of the treatment effect (Shadish, et al., 2002; Thistlethwaite \& Campbell, 1960; Trochim, 1984). Thus, if a non-linear relationship represents the true functional form of the model, then higher order terms and their respective interactions would need to be added to the baseline regression-discontinuity model (Lesik, 2008; Schumacker \& Mount, 2007; Shadish, et al., 2002; Trochim, 1984). Equation (2) is a regression-discontinuity model that includes higher-order terms and interactions in addition to the baseline regression-discontinuity model. 


\section{REGRESSION-DISCONTINUITY DESIGN FOR PROGRAM EVALUATION}

$Y=\beta_{0}+\beta_{1}$ TREATMENT $+\beta_{2}$ ASSIGNMENT

$+\beta_{3}$ ASSIGNMENT ${ }^{2}+\beta_{4}$ TREATMENT $\cdot$ ASSIGNMENT ${ }^{2}$

$+\beta_{5}$ ASSIGNMENT ${ }^{3}+\beta_{6}$ TREATMENT $\cdot$ ASSIGNMENT ${ }^{3}$

$+\ldots+\beta_{k}$ ASSIGNMENT ${ }^{j}$

$+\beta_{k+1}$ TREATMENT $^{\prime}$ ASSIGNMENT ${ }^{j}+\mathcal{E}$

Many studies that have used the regression-discontinuity design have either employed exploratory techniques to empirically estimate the functional relationship between the assignment and outcome variables (Jacob \& Lefgren, 2002; Lesik, 2006), or have added higher-order polynomial terms of the assignment variable along with possible interaction terms and then tested to determine if such terms are significant (Lesik, 2008; Moss \& Yeaton, 2006). One concern with including higher-order terms and interactions in a regression-discontinuity design is that it can difficult to estimate the correct functional form by visualization. Furthermore, adding extra terms to the regression-discontinuity model reduces the power of the design (Cappelleri \& Trochim, 1994). Similarly, with the sample size limitations of the regression-discontinuity design, researchers often have to extrapolate more observations above and below the cutoff score in order to obtain a sufficiently large sample and then try to model the functional form appropriately (Lesik, 2006; Moss \& Yeaton, 2006; Shadish, et al., 2002).

Clearly, a trade-off exists between the number of observations collected around the cutoff score and the functional form specification of the regression-discontinuity model. Collecting too few observations around the cutoff score would require including more observations that are further away from the cutoff score, thus making it more difficult to describe the appropriate functional form. Collecting a small number of observations that lie only within a very narrow range around the cutoff score may not provide enough power to detect a reasonably sized effect.

Although the functional form and sample size limitations of the regressiondiscontinuity design can be difficult to address in practice, one of the most serious limitations of the design occurs when participants do not adhere to their assignment that is based only on the score received on the assignment measure. Typically, in order to address such noncompliance, researchers have modeled selection effects by using the probability of actually participating in the treatment program as an instrumental variable for the program assignment (Lesik, 2006).

The technique of instrumental variable estimation measures the effect of the treatment rather than just the assignment to the treatment group (Angrist \& Krueger, 1991; Jacob \& Lefgren, 2002). However, most research using instrumental variables estimation has the first stage probability of actually participating in the program described by a linear probability model (Lesik, 2006; 2007), and this introduces some of the limitations of the linear probability model, such as probabilities greater than one or less than zero (Wooldridge, 2003). Nonlinear firststage instrumental variables estimation tends not to be used in practice because their behavior is generally not well known (Wooldridge, 2002). Another concern with using instrumental variables estimation is that this technique on in its own relies on some very strong assumptions which can be difficult to assess in practice (Wooldridge, 2002, 2003).

A simpler strategy to assess the effect of non-compliance in a regression-discontinuity analysis is to determine how much of an effect keeping those observations that did not comply with their assignment in the model. A basic sensitivity analysis can be used to determine if the estimate of the treatment effect is different when including and excluding non-compliers in the model (Leake \& Lesik, 2007). However, there remains the need to establish some general guidelines that can be used to assess whether the amount of non-compliance could be introducing bias in the estimate of the treatment effect if these observations are included in the analysis, as well as to determine what happens to the estimate of the treatment effect when noncompliers are removed from the analysis.

\section{Methodology}

In order to address the impact of noncompliance on the estimate of the treatment effect as obtained through a regression- 
discontinuity design, the results of a simulation analysis are presented within the framework of an ordinary least squares regression. The simulation analysis was executed using Version 10 of STATA ${ }^{\circledR}$ (STATA Corporation, 2007).

\section{Simulation Analysis}

A simulation analysis was performed to investigate how participant noncompliance can impact the estimate of the treatment effect in a regression-discontinuity design within the framework of ordinary least squares regression. The challenge with running a simulation analysis for a regression-discontinuity design revolves around simulating realistic regressiondiscontinuity data. Figure 1 illustrates a hypothetical regression-discontinuity design (Shadish, et al., 2002). A perfect regressiondiscontinuity indicates $100 \%$ compliance.

Perfect compliance is when those participants who were assigned to the treatment group actually did participate in the treatment, and those who were assigned to the control group did not participate in the treatment at all.
Notice that the discontinuity in Figure 1 represents a simulated treatment effect of -0.50 at the cutoff score of 0 .

In order to generate realistic regressiondiscontinuity data, a random component was introduced (see Figure 2). Figure 2 shows the scatter plot along with the lines of best fit and a lowess smoother estimating the relationship between the assignment variable and the outcome variable. The random component was fixed at one-half of the effect size to ensure that a linear model would be appropriate.

Appendix 1 contains an example of how Stata code can be written to simulate the regression-discontinuity data presented in Figure 2. This Stata code randomly generates 50 observations on the interval $(-1,1)$, which centers about the cutoff score of 0 . Observations that are greater than or equal to zero are assigned the value 0 to represent that they are assigned to the control group, whereas all other observations that fall below the cutoff score of 0 are assigned to the treatment program and given the value 1 .

Figure 1: Simulated Regression-Discontinuity Data with an Effect Size of -0.50 At the Centered Cutoff Score of 0

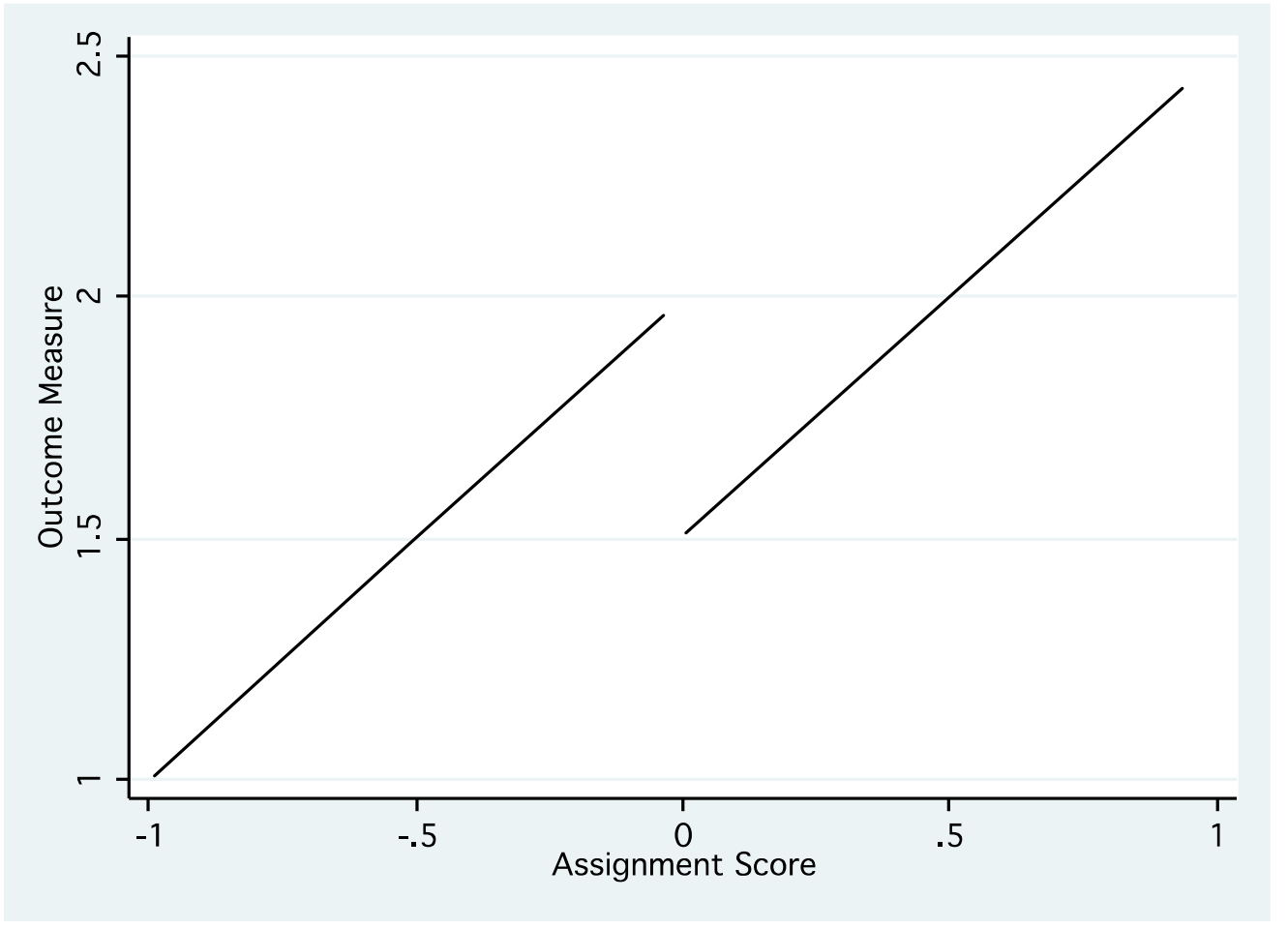




\section{REGRESSION-DISCONTINUITY DESIGN FOR PROGRAM EVALUATION}

Figure 2: Regression-Discontinuity Data with Added Random Component of 0.25 and a -0.5 Discontinuity at the Centered Cutoff Score of 0

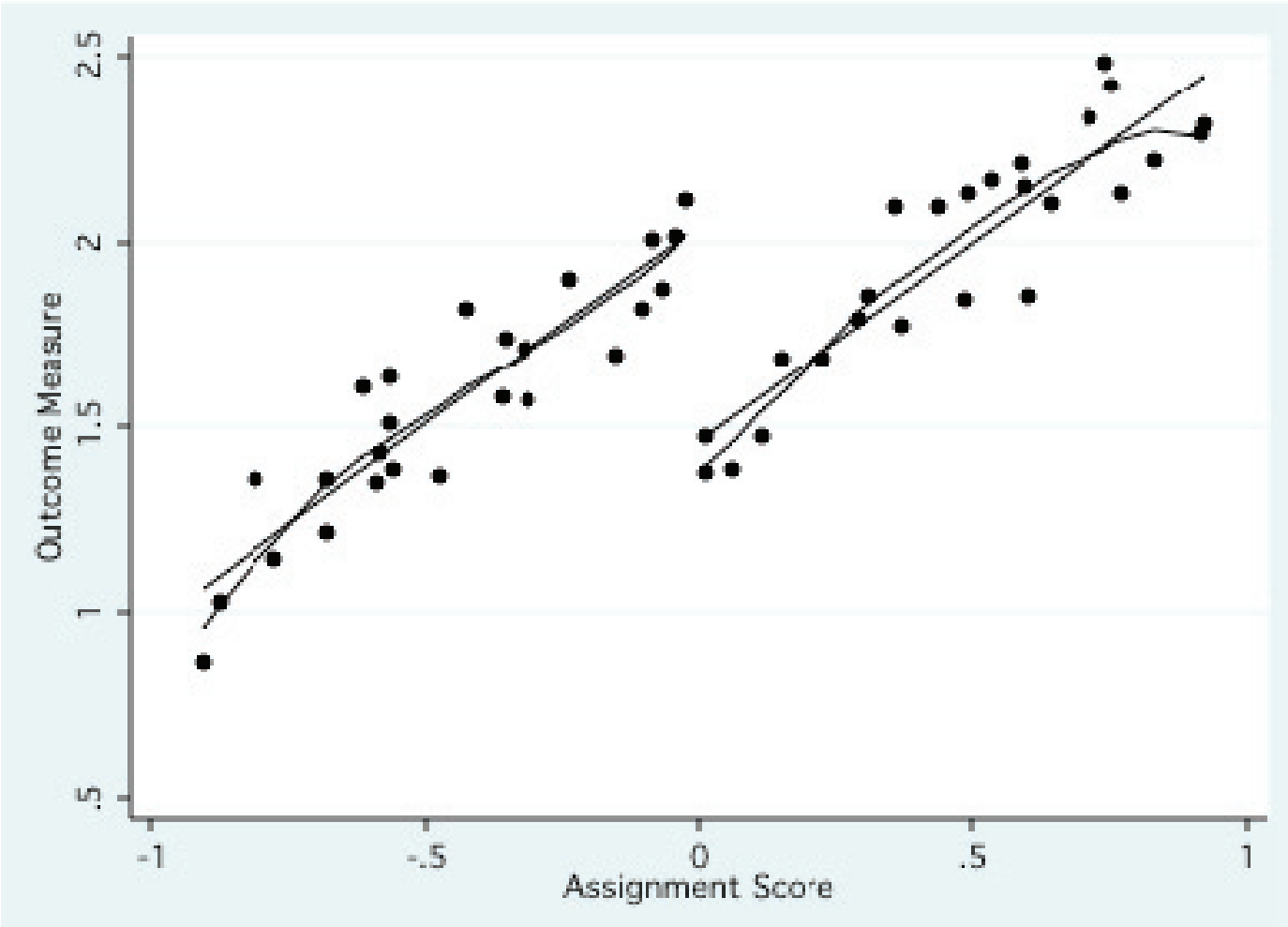

This example illustrates a random component that is generated between -0.25 and 0.25 from the original data: In other words, each observation is randomly assigned to be within \pm 0.25 of its original value. The simulated treatment effect of 0.50 is generated for those observations that are assigned to the treatment group so around the cutoff score of 0 , the treatment effect remains at 0.50 . The choice of considering a small interval around the cutoff score and of having the random component equal to half of the effect size was introduced to generate what realistic regression-discontinuity data would look like and to ensure a linear model specification is appropriate.

In order to generate non-compliers, a random number on the interval $[0,1)$ was generated and, for each observation, this random number was compared to the given percent of non-compliance. If the observation was designed as a crossover because the random number was less than the given percentage of non-noncompliance, then the treatment indicator was changed for these observations.

\section{Results}

A series of Monte Carlo simulations were run to investigate the impact of sample size, noncompliance and the effect size on the estimate of the treatment effect when non-compliers were kept in the analysis, when there was perfect compliance, and when non-compliers were deleted from the analysis. A total of 10,000 simulations were run for each of the different combinations of effect sizes, sample sizes, and percentages of non-compliance. Table 2 shows the estimate of the treatment effect and standard error for including non-compliers in the analysis, with perfect compliance and for deleting noncompliers from the analysis.

The results of the simulation analysis indicate that for any sample size, any effect size and any degree of non-compliance, keeping non- 


\section{SALLY A. LESIK}

compliers in the analysis will generate a biased estimate of the treatment effect. Also interesting is that larger sample sizes show greater bias as compared to smaller samples even for the same percent of non-compliance. In addition, as the degree of non-compliance increases, the estimate of the treatment effect becomes more biased. Furthermore, for any degree of noncompliance less than $10 \%$, running the regression-discontinuity analysis without the non-compliers generates similar estimates of the treatment effect than was found assuming perfect compliance. This is consistent with Judd and Kenny (1981) and Trochim (1984), who suggest that excluding no more than $5 \%$ of the non-compliers should provide reasonable estimates of the treatment effect.

This simulation analysis illustrates that if non-compliance is random - then excluding no more than $10 \%$ of the observations provides a reasonable estimate of the treatment effect. It is also interesting to note that analyses with greater effect sizes show a similar bias compared to smaller effect sizes. For example, for a sample of 500 with an effect size of 0.500 , if $10 \%$ of the observations are non-compliers and if they are kept in the analysis, then the estimated effect size becomes 0.193 , a reduction of approximately $60 \%$. For a sample of 500 with an effect size of 2.000 , if $10 \%$ of the observations are non-compliers and they are kept in the analysis, then the estimated effect size becomes 0.775 , again a reduction of approximately $60 \%$. Similarly for a sample size of 20 with $1 \%$ of the non-compliers kept in the analysis, then the estimated effect size becomes 0.458 for an effect size of 0.500 , a reduction of approximately $8 \%$, and for a sample of size 20 with $1 \%$ of the noncompliers kept in the analysis, then the estimated effect size becomes 1.834 for an effect size of 2.000 , again a reduction of approximately $8 \%$.

\section{Conclusion}

Although this study contributes to the literature by providing some guidelines for dealing with the noncompliance limitation of the regressiondiscontinuity design, this study did not address other issues such as attrition or numerous other threats to validity that are inherent with virtually every type of analyses (Shadish, et al., 2002).
Furthermore, because the range of data collected around the cutoff score was fixed to only include those observations within one point of the centered cutoff score of 0 the issue of correct functional form for this study was not relevant. However, as is often the case in practice, more observations need to be collected around a greater range of the cutoff score, and thus functional form specification becomes more of a concern. In this simulation, the functional form was forced to be approximately linear in order to avoid trying to model functional form and noncompliance together.

Results of the simulation analysis suggest that if non-compliance is essentially a random phenomenon, then removing the noncompliers from the analysis does not appear to bias the estimate of the treatment effect if the percentage of non-compliers is relatively small, such as less than $10 \%$. However, if noncompliance is not random, then this may not be the case. For example, if only those participants who were on one side of the cutoff score chose not to comply with their assignment, then deleting them from the analysis will likely produce a biased estimate of the treatment effect. In cases where non-compliance is not random, instrumental variables estimation may be a better strategy to use, even given the relatively strong assumptions of instrumental variables estimation.

\section{References}

Angrist, J., \& Krueger, A. (1991). Does compulsory school attendance affect schooling and earnings? Quarterly Journal of Economics, 106, 9791014.

Cappelleri, J., Darlington, R., \& Trochim, W. (1994). Power analysis of cutoff-based randomized clinical trials. Evaluation Review, 18, 141-152.

Cappelleri, J., \& Trochim, W. (1994). An illustrative statistical analysis of cutoff-based randomized clinical trials. Journal of Clinical Epidemiology, 47, 261-270.

Jacob, B., \& Lefgren, L. (2002). Remedial education and student achievement: A regressiondiscontinuity analysis (Working paper 8918). Cambridge, MA: National Bureau of Economic Research. 


\section{REGRESSION-DISCONTINUITY DESIGN FOR PROGRAM EVALUATION}

Judd, C., \& Kenny, D. (1981). Estimating the Effects of Social Interventions. London, England: Cambridge University Press.

Leake, M., \& Lesik, S. (2007). Do remedial English programs impact first-year success in college? An illustration of the regressiondiscontinuity design. International Journal of Research and Method in Education, 30(1), 89-99.

Lesik, S. (2006). Applying the regressiondiscontinuity design to infer causality with nonrandom assignment. The Review of Higher Education, 30(1), 1-19.

Lesik, S. (2007). Do developmental mathematics programs have a causal impact on student retention? An application of discrete-time survival and regression-discontinuity analysis. Research in Higher Education, 48(5), 583-608.

Lesik, S. (2008). Studying the Effectiveness of Programs and Initiatives in Higher Education Using the Regression-Discontinuity Design. In J. C. Smart (Ed.), Higher Education Handbook of Theory and Research, Volume 23. The Netherlands: Springer Business Media.

Luyten, H. (2006). An empirical assessment of the absolute effect of schooling: regressiondiscontinuity applied to TIMSS-95. Oxford Review of Education, 32(3), 397-429.

Moss, B., \& Yeaton, W. (2006). Shaping policies related to developmental education: An evaluation using the regression-discontinuity design. Educational Evaluation and Policy Analysis, 28(3), 215-229.

Pettersson-Lidbom, P. (2003). Do parties matter for fiscal policy choices? A regressiondiscontinuity approach. Stockholm, Sweden: Stockholm University.

Ross, A., \& Lacey, B. (1983). A regression discontinuity analysis of a remedial education programme. Canadian Journal of Higher Education, 13(1), 1-15.

Schumacker, R., \& Mount, R. (2007). Regression discontinuity: Examining model misspecification. Paper presented at the Paper presented at the annual meeting of the American Educational Research Association, Chicago, IL.

Shadish, W., Cook, T., \& Campbell, D. (2002). Experimental and Quasi-experimental Designs for Generalized Causal Inference. Boston, MA: Houghton Mifflin.

STATA Corporation. (2007). STATA Base Reference Manual (Vol. 1). College Station, TX: STATA Press.

Thistlethwaite, D., \& Campbell, D. (1960). Regression-discontinuity analysis: An alternative to the ex post facto experiment. Journal of Educational Psychology, 51, 309-317.
Trochim, W. (1984). Research Design for Program Evaluation: The Regression -Discontinuity Approach. Newbury Park, CA: Sage.

vanDerKlaauw, W. (2002). Estimating the effect of financial aid offers on college enrollment: A regression-discontinuity approach. International Economic Review, 43(4), 1249-1287.

Wooldridge, J. (2002). Econometric Analysis of Cross Section and Panel Data. Cambridge, MA: The MIT Press.

Wooldridge, J. (2003). Introductory Econometrics: A Modern Approach ( $2^{\text {nd }}$ Ed.). Mason, Ohio: South-Western.

\section{Appendix 1: Example of Stata Code for Simulation Analysis}

program rdgen, rclass

version 10.1

drop_all

$$
\begin{aligned}
& \text { set obs } 50 \\
& \text { generate } \mathrm{x}=-1+(1-(-1)) * \text { uniform }() \\
& \text { generate treat }=1 \\
& \text { replace treat }=0 \text { if } x>=0 \\
& \text { generate } \mathrm{y}=\mathrm{x}+2 \\
& \text { replace } \mathrm{y}=(\mathrm{y}-0.05) \text { if treat }==0 \\
& \text { generate } \mathrm{z}=-0.25+(0.25-(- \\
& 0.25)) * \text { uniform() } \\
& \text { generate crossover }=0 \\
& \text { generate } \mathrm{w}=\text { uniform }() \\
& \text { generate treatcr }=\text { treat } \\
& \text { replace treatcr }=\text { treat }+1 \text { if } \mathrm{w}<0.05 \\
& \text { replace crossover }=1 \text { if } \mathrm{w}<0.05 \\
& \text { replace treatcr }=0 \text { if treatcr }==2 \\
& \text { replace } \mathrm{y}=\mathrm{z}+\mathrm{y} \\
& \text { regress } \mathrm{y} \text { treatcr } \mathrm{x} \\
& \text { return scalar } \mathrm{B} 1 \mathrm{cr}=\mathrm{b}[\text { treatcr }] \\
& \text { return scalar seB } 1 \mathrm{cr}=\text { = } \mathrm{se}[\text { treatcr] } \\
& \text { regress } \mathrm{y} \text { treat } \mathrm{x} \\
& \text { return scalar } \mathrm{B} 1=\mathrm{b} \text { [treat }] \\
& \text { return scalar seB1 = _se[treat] } \\
& \text { drop if crossover }==\overline{1} \\
& \text { regress } \mathrm{y} \text { treat } \mathrm{x} \\
& \text { return scalar B1 nocr }=\text { b }[\text { [treat }] \\
& \text { return scalar seB1 nocr } \left.=\_ \text {se[treat }\right]
\end{aligned}
$$

end 
SALLY A. LESIK

Table 2: Estimate of the Treatment Effect and Standard Error (in [ ]) for Simulated Regression-Discontinuity Data Including Non-Compliers (NC), with Perfect Compliance and Without Non-Compliers for Various Percentages of Non-Compliance (\% NC)

\begin{tabular}{|c|c|c|c|c|c|c|c|c|c|c|c|c|c|}
\hline \multirow[b]{2}{*}{$\begin{array}{l}\% \\
\mathrm{NC}\end{array}$} & $\begin{array}{l}\text { Sample } \\
\text { Size }\end{array}$ & $\begin{array}{l}\text { With } \\
\text { NC }\end{array}$ & Perfect & $\begin{array}{l}\text { Without } \\
\text { NC }\end{array}$ & $\begin{array}{l}\text { With } \\
\text { NC }\end{array}$ & Perfect & $\begin{array}{l}\text { Without } \\
\text { NC }\end{array}$ & $\begin{array}{l}\text { With } \\
\text { NC }\end{array}$ & Perfect & $\begin{array}{l}\text { Without } \\
\text { NC }\end{array}$ & $\begin{array}{l}\text { With } \\
\text { NC }\end{array}$ & Perfect & $\begin{array}{l}\text { Without } \\
\text { NC }\end{array}$ \\
\hline & $\begin{array}{c}\text { Effect } \\
\text { Size } \\
\end{array}$ & \multicolumn{3}{|c|}{0.500} & \multicolumn{3}{|c|}{1.000} & \multicolumn{3}{|c|}{1.500} & \multicolumn{3}{|c|}{2.000} \\
\hline \multirow{8}{*}{$1 \%$} & 20 & $\begin{array}{c}0.458 \\
{[0.135]}\end{array}$ & $\begin{array}{c}0.500 \\
{[0.137]}\end{array}$ & $\begin{array}{c}0.500 \\
{[0.138]}\end{array}$ & $\begin{array}{c}0.917 \\
{[0.270]}\end{array}$ & $\begin{array}{c}1.003 \\
{[0.273]}\end{array}$ & $\begin{array}{c}1.002 \\
{[0.275]}\end{array}$ & $\begin{array}{c}1.371 \\
{[0.405]}\end{array}$ & $\begin{array}{c}1.498 \\
{[0.410]}\end{array}$ & $\begin{array}{c}1.498 \\
{[0.412]}\end{array}$ & $\begin{array}{c}1.834 \\
{[0.541]}\end{array}$ & $\begin{array}{c}1.997 \\
{[0.548]}\end{array}$ & $\begin{array}{c}1.996 \\
{[0.551]}\end{array}$ \\
\hline & 30 & $\begin{array}{c}0.453 \\
{[0.108]}\end{array}$ & $\begin{array}{c}0.500 \\
{[0.110]}\end{array}$ & $\begin{array}{c}0.500 \\
{[0.110]}\end{array}$ & $\begin{array}{c}0.901 \\
{[0.216]}\end{array}$ & $\begin{array}{c}0.996 \\
{[0.219]}\end{array}$ & $\begin{array}{c}0.996 \\
{[0.220]}\end{array}$ & $\begin{array}{c}1.363 \\
{[0.324]}\end{array}$ & $\begin{array}{c}1.504 \\
{[0.329]}\end{array}$ & $\begin{array}{c}1.504 \\
{[0.330]}\end{array}$ & $\begin{array}{c}1.807 \\
{[0.432]}\end{array}$ & $\begin{array}{c}1.995 \\
{[0.439]}\end{array}$ & $\begin{array}{c}1.995 \\
{[0.441]}\end{array}$ \\
\hline & 40 & $\begin{array}{c}0.449 \\
{[0.093]}\end{array}$ & $\begin{array}{c}0.501 \\
{[0.094]}\end{array}$ & $\begin{array}{c}0.500 \\
{[0.094]}\end{array}$ & $\begin{array}{c}0.900 \\
{[0.186]}\end{array}$ & $\begin{array}{c}1.001 \\
{[0.187]}\end{array}$ & $\begin{array}{c}1.001 \\
{[0.188]}\end{array}$ & $\begin{array}{c}1.353 \\
{[0.278]}\end{array}$ & $\begin{array}{c}1.503 \\
{[0.281]}\end{array}$ & $\begin{array}{c}1.503 \\
{[0.283]}\end{array}$ & $\begin{array}{c}1.800 \\
{[0.371]}\end{array}$ & $\begin{array}{c}2.001 \\
{[0.375]}\end{array}$ & $\begin{array}{c}2.001 \\
{[0.377]}\end{array}$ \\
\hline & 50 & $\begin{array}{c}0.450 \\
{[0.083]}\end{array}$ & $\begin{array}{c}0.501 \\
{[0.084]}\end{array}$ & $\begin{array}{c}0.501 \\
{[0.084]}\end{array}$ & $\begin{array}{c}0.894 \\
{[0.165]}\end{array}$ & $\begin{array}{c}0.998 \\
{[0.167]}\end{array}$ & $\begin{array}{c}0.998 \\
{[0.168]}\end{array}$ & $\begin{array}{c}1.346 \\
{[0.248]}\end{array}$ & $\begin{array}{c}1.500 \\
{[0.250]}\end{array}$ & $\begin{array}{c}1.499 \\
{[0.251]}\end{array}$ & $\begin{array}{c}1.796 \\
{[0.330]}\end{array}$ & $\begin{array}{c}2.003 \\
{[0.333]}\end{array}$ & $\begin{array}{c}2.002 \\
{[0.335]}\end{array}$ \\
\hline & 100 & $\begin{array}{c}0.443 \\
{[0.058]}\end{array}$ & $\begin{array}{c}0.500 \\
{[0.058]}\end{array}$ & $\begin{array}{c}0.500 \\
{[0.059]}\end{array}$ & $\begin{array}{c}0.885 \\
{[0.116]}\end{array}$ & $\begin{array}{c}0.997 \\
{[0.117]}\end{array}$ & $\begin{array}{c}0.997 \\
{[0.117]}\end{array}$ & $\begin{array}{c}1.328 \\
{[0.174]}\end{array}$ & $\begin{array}{c}1.499 \\
{[0.175]}\end{array}$ & $\begin{array}{c}1.499 \\
{[0.176]}\end{array}$ & $\begin{array}{c}1.775 \\
{[0.231]}\end{array}$ & $\begin{array}{c}2.002 \\
{[0.233]}\end{array}$ & $\begin{array}{c}2.003 \\
{[0.234]}\end{array}$ \\
\hline & 200 & $\begin{array}{c}0.441 \\
{[0.041]}\end{array}$ & $\begin{array}{c}0.501 \\
{[0.041]}\end{array}$ & $\begin{array}{c}0.500 \\
{[0.041]}\end{array}$ & $\begin{array}{c}0.879 \\
{[0.082]}\end{array}$ & $\begin{array}{c}1.000 \\
{[0.082]}\end{array}$ & $\begin{array}{c}0.999 \\
{[0.082]}\end{array}$ & $\begin{array}{c}1.323 \\
{[0.122]}\end{array}$ & $\begin{array}{c}1.500 \\
{[0.123]}\end{array}$ & $\begin{array}{c}1.501 \\
{[0.124]}\end{array}$ & $\begin{array}{c}1.765 \\
{[0.163]}\end{array}$ & $\begin{array}{c}2.001 \\
{[0.164]}\end{array}$ & $\begin{array}{c}2.001 \\
{[0.165]}\end{array}$ \\
\hline & 300 & $\begin{array}{c}0.440 \\
{[0.033]}\end{array}$ & $\begin{array}{c}0.500 \\
{[0.033]}\end{array}$ & $\begin{array}{c}0.500 \\
{[0.034]}\end{array}$ & $\begin{array}{c}0.880 \\
{[0.066]}\end{array}$ & $\begin{array}{c}1.000 \\
{[0.067]}\end{array}$ & $\begin{array}{c}1.000 \\
{[0.067]}\end{array}$ & $\begin{array}{c}1.321 \\
{[0.100]}\end{array}$ & $\begin{array}{c}1.502 \\
{[0.100]}\end{array}$ & $\begin{array}{c}1.502 \\
{[0.101]}\end{array}$ & $\begin{array}{c}1.760 \\
{[0.133]}\end{array}$ & $\begin{array}{c}1.998 \\
{[0.134]}\end{array}$ & $\begin{array}{c}1.998 \\
{[0.134]}\end{array}$ \\
\hline & 500 & $\begin{array}{c}0.439 \\
{[0.026]}\end{array}$ & $\begin{array}{c}0.500 \\
{[0.026]}\end{array}$ & $\begin{array}{c}0.500 \\
{[0.026]}\end{array}$ & $\begin{array}{c}0.880 \\
{[0.051]}\end{array}$ & $\begin{array}{c}1.000 \\
{[0.052]}\end{array}$ & $\begin{array}{c}1.000 \\
{[0.052]}\end{array}$ & $\begin{array}{c}1.317 \\
{[0.077]}\end{array}$ & $\begin{array}{c}1.501 \\
{[0.078]}\end{array}$ & $\begin{array}{c}1.501 \\
{[0.078]}\end{array}$ & $\begin{array}{c}1.756 \\
{[0.103]}\end{array}$ & $\begin{array}{c}2.000 \\
{[0.104]}\end{array}$ & $\begin{array}{c}2.000 \\
{[0.104]}\end{array}$ \\
\hline \multirow{8}{*}{$5 \%$} & 20 & $\begin{array}{c}0.327 \\
{[0.127]}\end{array}$ & $\begin{array}{c}0.496 \\
{[0.137]}\end{array}$ & $\begin{array}{c}0.496 \\
{[0.143]}\end{array}$ & $\begin{array}{c}0.658 \\
{[0.255]}\end{array}$ & $\begin{array}{c}1.002 \\
{[0.274]}\end{array}$ & $\begin{array}{c}1.004 \\
{[0.282]}\end{array}$ & $\begin{array}{c}0.988 \\
{[0.382]}\end{array}$ & $\begin{array}{c}1.498 \\
{[0.411]}\end{array}$ & $\begin{array}{c}1.499 \\
{[0.423]}\end{array}$ & $\begin{array}{c}1.335 \\
{[0.511]}\end{array}$ & $\begin{array}{c}2.010 \\
{[0.548]}\end{array}$ & $\begin{array}{c}2.010 \\
{[0.564]}\end{array}$ \\
\hline & 30 & $\begin{array}{c}0.315 \\
{[0.102]}\end{array}$ & $\begin{array}{c}0.501 \\
{[0.109]}\end{array}$ & $\begin{array}{c}0.500 \\
{[0.113]}\end{array}$ & $\begin{array}{c}0.633 \\
{[0.204]}\end{array}$ & $\begin{array}{c}1.002 \\
{[0.219]}\end{array}$ & $\begin{array}{c}1.002 \\
{[0.226]}\end{array}$ & $\begin{array}{c}0.948 \\
{[0.305]}\end{array}$ & $\begin{array}{c}1.502 \\
{[0.328]}\end{array}$ & $\begin{array}{c}1.502 \\
{[0.338]}\end{array}$ & $\begin{array}{c}1.273 \\
{[0.407]}\end{array}$ & $\begin{array}{c}2.007 \\
{[0.436]}\end{array}$ & $\begin{array}{c}2.008 \\
{[0.449]}\end{array}$ \\
\hline & 40 & $\begin{array}{c}0.310 \\
{[0.087]}\end{array}$ & $\begin{array}{c}0.500 \\
{[0.094]}\end{array}$ & $\begin{array}{c}0.500 \\
{[0.097]}\end{array}$ & $\begin{array}{c}0.617 \\
{[0.175]}\end{array}$ & $\begin{array}{c}1.002 \\
{[0.187]}\end{array}$ & $\begin{array}{c}1.002 \\
{[0.193]}\end{array}$ & $\begin{array}{c}0.931 \\
{[0.262]}\end{array}$ & $\begin{array}{c}1.502 \\
{[0.281]}\end{array}$ & $\begin{array}{c}1.501 \\
{[0.289]}\end{array}$ & $\begin{array}{c}1.235 \\
{[0.350]}\end{array}$ & $\begin{array}{c}1.998 \\
{[0.375]}\end{array}$ & $\begin{array}{c}1.999 \\
{[0.386]}\end{array}$ \\
\hline & 50 & $\begin{array}{c}0.304 \\
{[0.079]}\end{array}$ & $\begin{array}{c}0.500 \\
{[0.084]}\end{array}$ & $\begin{array}{c}0.501 \\
{[0.086]}\end{array}$ & $\begin{array}{c}0.608 \\
{[0.156]}\end{array}$ & $\begin{array}{c}1.002 \\
{[0.167]}\end{array}$ & $\begin{array}{c}1.002 \\
{[0.172]}\end{array}$ & $\begin{array}{c}0.911 \\
{[0.233]}\end{array}$ & $\begin{array}{c}1.498 \\
{[0.250]}\end{array}$ & $\begin{array}{c}1.498 \\
{[0.257]}\end{array}$ & $\begin{array}{c}1.216 \\
{[0.311]}\end{array}$ & $\begin{array}{c}2.001 \\
{[0.334]}\end{array}$ & $\begin{array}{c}2.001 \\
{[0.343]}\end{array}$ \\
\hline & 100 & $\begin{array}{c}0.295 \\
{[0.054]}\end{array}$ & $\begin{array}{c}0.500 \\
{[0.058]}\end{array}$ & $\begin{array}{c}0.500 \\
{[0.060]}\end{array}$ & $\begin{array}{c}0.588 \\
{[0.109]}\end{array}$ & $\begin{array}{c}1.000 \\
{[0.117]}\end{array}$ & $\begin{array}{c}1.000 \\
{[0.120]}\end{array}$ & $\begin{array}{c}0.887 \\
{[0.163]}\end{array}$ & $\begin{array}{c}1.501 \\
{[0.175]}\end{array}$ & $\begin{array}{c}1.502 \\
{[0.180]}\end{array}$ & $\begin{array}{c}1.184 \\
{[0.218]}\end{array}$ & $\begin{array}{c}2.003 \\
{[0.233]}\end{array}$ & $\begin{array}{c}2.003 \\
{[0.240]}\end{array}$ \\
\hline & 200 & $\begin{array}{c}0.291 \\
{[0.038]}\end{array}$ & $\begin{array}{c}0.500 \\
{[0.041]}\end{array}$ & $\begin{array}{c}0.500 \\
{[0.042]}\end{array}$ & $\begin{array}{c}0.580 \\
{[0.077]}\end{array}$ & $\begin{array}{c}0.990 \\
{[0.082]}\end{array}$ & $\begin{array}{c}0.999 \\
{[0.084]}\end{array}$ & $\begin{array}{c}0.876 \\
{[0.115]}\end{array}$ & $\begin{array}{c}1.500 \\
{[0.123]}\end{array}$ & $\begin{array}{c}1.500 \\
{[0.126]}\end{array}$ & $\begin{array}{c}1.164 \\
{[0.153]}\end{array}$ & $\begin{array}{c}1.999 \\
{[0.164]}\end{array}$ & $\begin{array}{c}1.999 \\
{[0.169]}\end{array}$ \\
\hline & 300 & $\begin{array}{c}0.290 \\
{[0.031]}\end{array}$ & $\begin{array}{c}0.500 \\
{[0.033]}\end{array}$ & $\begin{array}{c}0.500 \\
{[0.034]}\end{array}$ & $\begin{array}{c}0.580 \\
{[0.062]}\end{array}$ & $\begin{array}{c}1.000 \\
{[0.067]}\end{array}$ & $\begin{array}{c}1.000 \\
{[0.069]}\end{array}$ & $\begin{array}{c}0.868 \\
{[0.094]}\end{array}$ & $\begin{array}{c}1.499 \\
{[0.100]}\end{array}$ & $\begin{array}{c}1.499 \\
{[0.103]}\end{array}$ & $\begin{array}{c}1.158 \\
{[0.125]}\end{array}$ & $\begin{array}{c}2.001 \\
{[0.134]}\end{array}$ & $\begin{array}{c}2.002 \\
{[0.137]}\end{array}$ \\
\hline & 500 & $\begin{array}{c}0.288 \\
{[0.024]}\end{array}$ & $\begin{array}{c}0.500 \\
{[0.026]}\end{array}$ & $\begin{array}{c}0.500 \\
{[0.027]}\end{array}$ & $\begin{array}{c}0.577 \\
{[0.048]}\end{array}$ & $\begin{array}{c}1.000 \\
{[0.052]}\end{array}$ & $\begin{array}{c}1.000 \\
{[0.053]}\end{array}$ & $\begin{array}{c}0.865 \\
{[0.072]}\end{array}$ & $\begin{array}{c}1.500 \\
{[0.078]}\end{array}$ & $\begin{array}{c}1.500 \\
{[0.080]}\end{array}$ & $\begin{array}{c}1.152 \\
{[0.096]}\end{array}$ & $\begin{array}{c}1.999 \\
{[0.104]}\end{array}$ & $\begin{array}{c}1.999 \\
{[0.106]}\end{array}$ \\
\hline
\end{tabular}




\section{REGRESSION-DISCONTINUITY DESIGN FOR PROGRAM EVALUATION}

Table 2 (continued): Estimate of the Treatment Effect and Standard Error (in [ ]) for Simulated Regression-Discontinuity Data Including Non-Compliers (NC), with Perfect Compliance and Without Non-Compliers for Various Percentages of Non-Compliance

\begin{tabular}{|c|c|c|c|c|c|c|c|c|c|c|c|c|c|}
\hline \multicolumn{14}{|c|}{$(\% \mathrm{NC})$} \\
\hline \multirow[b]{2}{*}{$\begin{array}{c}\% \\
\mathrm{NC} \\
\end{array}$} & $\begin{array}{l}\text { Sample } \\
\text { Size }\end{array}$ & $\begin{array}{l}\text { With } \\
\text { NC }\end{array}$ & Perfect & $\begin{array}{c}\text { Without } \\
\text { NC }\end{array}$ & $\begin{array}{l}\text { With } \\
\text { NC }\end{array}$ & Perfect & $\begin{array}{c}\text { Without } \\
\text { NC }\end{array}$ & $\begin{array}{l}\text { With } \\
\text { NC }\end{array}$ & Perfect & $\begin{array}{c}\text { Without } \\
\text { NC }\end{array}$ & $\begin{array}{l}\text { With } \\
\text { NC }\end{array}$ & Perfect & $\begin{array}{c}\text { Without } \\
\text { NC }\end{array}$ \\
\hline & $\begin{array}{l}\text { Effect } \\
\text { Size }\end{array}$ & \multicolumn{3}{|c|}{0.500} & \multicolumn{3}{|c|}{1.000} & \multicolumn{3}{|c|}{1.500} & \multicolumn{3}{|c|}{2.000} \\
\hline \multirow{8}{*}{$10 \%$} & 20 & $\begin{array}{c}0.229 \\
{[0.119]}\end{array}$ & $\begin{array}{c}0.502 \\
{[0.137]}\end{array}$ & $\begin{array}{c}0.503 \\
{[0.146]}\end{array}$ & $\begin{array}{c}0.450 \\
{[0.236]}\end{array}$ & $\begin{array}{c}1.000 \\
{[0.274]}\end{array}$ & $\begin{array}{c}1.001 \\
{[0.292]}\end{array}$ & $\begin{array}{c}0.671 \\
{[0.354]}\end{array}$ & $\begin{array}{c}1.504 \\
{[0.410]}\end{array}$ & $\begin{array}{c}1.503 \\
{[0.436]}\end{array}$ & $\begin{array}{c}0.903 \\
{[0.474]}\end{array}$ & $\begin{array}{c}2.002 \\
{[0.548]}\end{array}$ & $\begin{array}{c}2.005 \\
{[0.584]}\end{array}$ \\
\hline & 30 & $\begin{array}{c}0.214 \\
{[0.094]}\end{array}$ & $\begin{array}{c}0.500 \\
{[0.110]}\end{array}$ & $\begin{array}{c}0.500 \\
{[0.116]}\end{array}$ & $\begin{array}{c}0.429 \\
{[0.189]}\end{array}$ & $\begin{array}{c}1.002 \\
{[0.218]}\end{array}$ & $\begin{array}{c}1.001 \\
{[0.232]}\end{array}$ & $\begin{array}{c}0.645 \\
{[0.283]}\end{array}$ & $\begin{array}{c}1.505 \\
{[0.328]}\end{array}$ & $\begin{array}{c}1.504 \\
{[0.348]}\end{array}$ & $\begin{array}{c}0.853 \\
{[0.376]}\end{array}$ & $\begin{array}{c}1.999 \\
{[0.437]}\end{array}$ & $\begin{array}{c}2.001 \\
{[0.464]}\end{array}$ \\
\hline & 40 & $\begin{array}{c}0.206 \\
{[0.081]}\end{array}$ & $\begin{array}{c}0.500 \\
{[0.094]}\end{array}$ & $\begin{array}{c}0.500 \\
{[0.099]}\end{array}$ & $\begin{array}{c}0.416 \\
{[0.161]}\end{array}$ & $\begin{array}{c}1.002 \\
{[0.187]}\end{array}$ & $\begin{array}{c}1.002 \\
{[0.198]}\end{array}$ & $\begin{array}{c}0.619 \\
{[0.242]}\end{array}$ & $\begin{array}{c}1.495 \\
{[0.281]}\end{array}$ & $\begin{array}{c}1.497 \\
{[0.297]}\end{array}$ & $\begin{array}{c}0.830 \\
{[0.323]}\end{array}$ & $\begin{array}{c}1.995 \\
{[0.375]}\end{array}$ & $\begin{array}{c}1.998 \\
{[0.397]}\end{array}$ \\
\hline & 50 & $\begin{array}{c}0.205 \\
{[0.072]}\end{array}$ & $\begin{array}{c}0.500 \\
{[0.083]}\end{array}$ & $\begin{array}{c}0.500 \\
{[0.088]}\end{array}$ & $\begin{array}{c}0.405 \\
{[0.143]}\end{array}$ & $\begin{array}{c}0.996 \\
{[0.167]}\end{array}$ & $\begin{array}{c}0.997 \\
{[0.177]}\end{array}$ & $\begin{array}{c}0.610 \\
{[0.215]}\end{array}$ & $\begin{array}{c}1.496 \\
{[0.251]}\end{array}$ & $\begin{array}{c}1.496 \\
{[0.265]}\end{array}$ & $\begin{array}{c}0.817 \\
{[0.287]}\end{array}$ & $\begin{array}{c}1.999 \\
{[0.333]}\end{array}$ & $\begin{array}{c}2.000 \\
{[0.353]}\end{array}$ \\
\hline & 100 & $\begin{array}{c}0.197 \\
{[0.050]}\end{array}$ & $\begin{array}{c}0.500 \\
{[0.058]}\end{array}$ & $\begin{array}{c}0.501 \\
{[0.062]}\end{array}$ & $\begin{array}{c}0.395 \\
{[0.100]}\end{array}$ & $\begin{array}{c}1.002 \\
{[0.117]}\end{array}$ & $\begin{array}{c}1.002 \\
{[0.123]}\end{array}$ & $\begin{array}{c}0.595 \\
{[0.150]}\end{array}$ & $\begin{array}{c}1.502 \\
{[0.175]}\end{array}$ & $\begin{array}{c}1.503 \\
{[0.185]}\end{array}$ & $\begin{array}{c}0.791 \\
{[0.200]}\end{array}$ & $\begin{array}{c}2.002 \\
{[0.233]}\end{array}$ & $\begin{array}{c}2.002 \\
{[0.246]}\end{array}$ \\
\hline & 200 & $\begin{array}{c}0.195 \\
{[0.035]}\end{array}$ & $\begin{array}{c}0.500 \\
{[0.041]}\end{array}$ & $\begin{array}{c}0.500 \\
{[0.043]}\end{array}$ & $\begin{array}{c}0.388 \\
{[0.070]}\end{array}$ & $\begin{array}{c}1.000 \\
{[0.082]}\end{array}$ & $\begin{array}{c}1.000 \\
{[0.087]}\end{array}$ & $\begin{array}{c}0.582 \\
{[0.105]}\end{array}$ & $\begin{array}{c}1.498 \\
{[0.123]}\end{array}$ & $\begin{array}{c}1.498 \\
{[0.130]}\end{array}$ & $\begin{array}{c}0.781 \\
{[0.141]}\end{array}$ & $\begin{array}{c}2.001 \\
{[0.164]}\end{array}$ & $\begin{array}{c}2.001 \\
{[0.173]}\end{array}$ \\
\hline & 300 & $\begin{array}{c}0.194 \\
{[0.029]}\end{array}$ & $\begin{array}{c}0.500 \\
{[0.033]}\end{array}$ & $\begin{array}{c}0.500 \\
{[0.035]}\end{array}$ & $\begin{array}{c}0.389 \\
{[0.057]}\end{array}$ & $\begin{array}{c}1.000 \\
{[0.067]}\end{array}$ & $\begin{array}{c}1.000 \\
{[0.071]}\end{array}$ & $\begin{array}{c}0.582 \\
{[0.086]}\end{array}$ & $\begin{array}{c}1.498 \\
{[0.100]}\end{array}$ & $\begin{array}{c}1.498 \\
{[0.106]}\end{array}$ & $\begin{array}{c}0.773 \\
{[0.114]}\end{array}$ & $\begin{array}{c}1.998 \\
{[0.134]}\end{array}$ & $\begin{array}{c}1.998 \\
{[0.141]}\end{array}$ \\
\hline & 500 & $\begin{array}{c}0.193 \\
{[0.022]}\end{array}$ & $\begin{array}{c}0.500 \\
{[0.026]}\end{array}$ & $\begin{array}{c}0.500 \\
{[0.027]}\end{array}$ & $\begin{array}{c}0.387 \\
{[0.044]}\end{array}$ & $\begin{array}{c}1.000 \\
{[0.052]}\end{array}$ & $\begin{array}{c}1.000 \\
{[0.055]}\end{array}$ & $\begin{array}{c}0.579 \\
{[0.066]}\end{array}$ & $\begin{array}{c}1.499 \\
{[0.078]}\end{array}$ & $\begin{array}{c}1.499 \\
{[0.082]}\end{array}$ & $\begin{array}{c}0.775 \\
{[0.088]}\end{array}$ & $\begin{array}{c}2.000 \\
{[0.103]}\end{array}$ & $\begin{array}{c}2.001 \\
{[0.109]}\end{array}$ \\
\hline
\end{tabular}

